\title{
Environmental Education and Waste Management Behavior Among Undergraduate Students of the University of Calabar, Nigeria
}

\author{
Eneji, Chris-Valentine Ogar Onnoghen, Usang Nkannu Edung, Asuquo Etim Effiong, Grace Okon \\ Dept. of Environmental Education, University of Calabar, Nigeria \\ Corresponding author: Eneji, Chris-Valentine Ogar (PhD)
}

\begin{abstract}
This study set out to examine the role Environmental Education can play in influencing Environmental Education student's waste management behavior among undergraduate's students of the University of Calabar. Three purposes were pursued, where three research questions and two null hypotheses were formulated to guide the study. The research design adopted is the survey inferential research design. 212 respondents were selected as sample from a population of 568 students registered in the department of Environmental Education (both NUC and CES streams). a structured questionnaire with the four point Likert scale modified response options. A total of 212 questionnaires were administered to the respondents in their various classes, before lectures and same were retrieved. Data generated from the field was coded and analyzed using simple percentage and Pearson Product Moment Correlation Analysis at0.05 significance level and at 210 degree of freedom. It was discovered that the waste management behavior of undergraduate students are negative, their waste disposal methods include "throw away mentality', burning and dumping into gutter and drainages. The Correlation analyses show a positive significant relationship between Environmental Education and student's waste management behavior among undergraduate students of the University of Calabar. The study also found that Environmental Education can influence the waste disposal methods adopted by undergraduate students of Environmental Education in the University of Calabar. It was concluded that Environmental Education has the magic wand that can influence positive environmental attitude, behavior and perception towards positive waste management. It was recommended among others that Environmental Education should be introduced into our school curriculums at all level.
\end{abstract}

Keywords: Environmental Education, waste management behavior, waste disposal methods, waste management attitude and waste perception

DOI: 10.7176/JEP/10-24-11

Publication date: August 31st 2019

\section{Introduction}

From prehistoric times, human beings had lived all their lives depending on what the environment can provide for their food, shelter, clothing, medicine and every other thing that can make life comfortable. When man was a primitive man, to the extent where he became a hunter-gatherer, his impact on the environment was not noticed or at best, very minimal, until he became a settler, a peasant farmer and his population began to increase, there and then, man began to think on how to provide for his teaming population. When man developed to produce his food and other services to improve his condition of living, man started producing waste. Majorly, most of human waste generated stems from man's production and consumption pattern.

Man's production and consumption pattern has created a lot of environmental waste and resources depletion in most part of the world, how these waste and resource depletion can be managed or remedied has become a major source of concern to most environmental scientist and other stakeholders in the environmental business. Waste is most generated in developed countries than in developing countries. These wastes come in form of nuclear waste, industrial waste, domestic waste, commercial and institutional waste and others from mining and exploration sites. Wastes from developed countries have more debilitating and deleterious effects than those from developing countries (Ifegbesan, 2010; Lee and Hae, 2011; Desa, Abd Kadir and Yusooff, 2012).

Most wastes produced from developing countries are waste from primary production, domestic and food remains, and agricultural waste and very minimal from cottage industries and mining sites. The environment provides a basis for living. Its quality determines to a large extent, the quality of life enjoyed by its inhabitants. Man is constantly involved in a variety of activities which tends to reduce the quality of the environment, which in turn threaten man's existence on earth. Environmental degradation is used to describe a situation in which a part of the natural environment is damage (i.e) or endangered the land, water bodies, air or the forests and all its resources, (Yau, 2010; Wan, Shen and Yu, 2015).

Institutional wastes are mostly waste generated from waste papers, wrappers, domestic and food remains and other materials. These wastes are usually thrown indiscriminately within the schools in most developing countries because their technology for managing these waste are still in the developing stage. One of the major components 
of Environmental Education is waste and pollution management. Waste management involves the generation, collection, transportation and disposal of waste, be it solid, liquid or gaseous waste. In most educational institution, students, staff and other people generate different sets of waste, these waste are seldom attended to, in most cases, the students and staffs who generate these waste have some negative attitude towards the way the throw way such waste without necessarily putting them in waste bins or waste collection bins. The students over the years have developed the "throw away attitude" and they dispose of waste anywhere they like. This condition has become worrisome in recent time.

The extent to which the institution manages these waste too is still very worrisome and disturbing, especially where daily paid workers are employed to manage the institution's waste. Different waste management approaches have been employed to see if the institutional waste can be properly managed, but the students and some staffs are far from imbibing such management behavior, strategies and approach. This behavior boils down to the attitude that determines their waste management behavior in the University of Calabar. Most scholars see Environmental Education as having the remedy for the waste management behavior of undergraduate students in the University of Calabar, but how the course has the cure is the question that is left to be answered.

Environmental Education is all educational activities that foster the development of environmentally literate citizens. Environmental Education is an organized effort to teach people about how the eco-system functions and how human beings manage their eco-system in order to live a sustainable life (Smith, 2010).

Environmental Education is a learning process that increases people's knowledge and awareness about the environment and its associated challenges, and foster's attitude, motivations and commitments to make informed decisions and take responsible action (Ford Foundation, 2005 cited in Eneji, 2017). It also refers to organized efforts to teach about how natural environment function and particularly, how human beings can manage their behavior and ecosystems in order to live sustainably, (Gruenewald, 2004 in Eneji, 2017). Note that Environmental Education does not advocate a particular viewpoint or course of action, rather, Environmental Education teaches individuals how to weigh various sides of an issue through critical thinking thereby enhancing their own problemsolving and decision-making skill, (Pakpour, Zeidi, Emamjomeh, Asefzadeh and Pearson, 2014).

Eneji, (2017) observed that Environmental Education is a process that allows individuals to explore environmental issues, engage in problem solving, and take action to improve the environment. As a result, individuals develop a deeper understanding of environmental issues and have the skills to make informed and responsible decision. Eneji, (2017) further posited that the Environmental Education has its vision, mission, objectives, aims and goals thus:

Vision: The vision of Environmental Education is to develop a people who will use the environmental knowledge so acquired to engage in environmental stewardship.

Mission: The mission of Environmental Education is to ensure that Environmental Education, based on sound science and effective education practices, is used as a tool to promote and protect human health and the environment and to encourage student academic achievements.

Strategic goals: The global strategic goals of Environmental Education include:

Goal 1: promote the use of Environmental Education in schools and communities to improve academic achievement and stewardship

Goal 2: increase the capacity of states to develop and deliver comprehensive statewide Environmental Education programs

Goal 3: promote research and evaluation that assesses the effectiveness of Environmental Education in improving environmental quality and student's achievements.

Goal 4: improve quality, access and coordination of Environmental Education information, resources and programs.

Goal 5: promote and encourage environmental career.

Eneji, (2017) following Nigeria's rectification of all protocols and membership from the Brundtland convention to the Kyoto protocol, Nigeria have found the goals of networking with other stakeholders in Environmental Education, these goals include:

- Promote awareness and understanding of Environmental Education and its roles in formal and informal education system

- Provide a forum for members to network and discuss issues related to Environmental Education

- Provide programs and resources for Environmental Education and play an advocacy role in support of Environmental Education

- Promote Environmental Education as an essential education program

- Environmental Education has a crossover with other disciplines of outdoor education and experiential education. Both disciplines compliment Environmental Education, yet have unique philosophies and characteristics.

Objectives of Environmental Education are:

- Awareness- to help social groups and individuals acquire awareness and sensitivity towards "the environment as a whole and; ''issues, questions and problems related to environment and development 
- Knowledge- to help individuals and societies gain a variety of experience in, and acquire a basic understanding of what is required to create and maintain a sustainable environment

- Attitudes- to help individuals, groups and societies acquire: a set of values and feelings of concern for the environment, and 'the motivation to actively participate in protection of the environment

- Skills- help individuals, groups and societies acquire the skills for "'identifying", ''anticipating', preventing and "solving environmental problems

- Participation - to provide individuals, groups and societies with an opportunity and the motivation to be actively involved at all levels in creating a sustainable environment. While each of these disciplines has their own objectives, there are points where both disciplines overlap with the intention and philosophy of Environmental Education.

Environmental Education is an education type that creates in the learners the skills, attitude, value, knowledge and participation in solving the current environmental problems, while avoiding the creation of new ones. Environmental Education has been identified as a major vehicle for the solution of environmental problems, having stated so; there is the urgent concern to understand why students have developed such reckless attitude towards waste generation and disposal. Arising from the preposition that Environmental Education has the capacity to solve environmental problems, why then are the students of University of Calabar throwing their waste the way they like? Can Environmental Education bring about the required attitude towards waste management and disposal?

It is on the basis of this that this research is initiated to examine the role Environmental Education can play in influencing the waste management behavior of undergraduate students' in the University of Calabar, Nigeria. Environmental Education is all about engaging students, community members, policy makers, the young and the old. It is about empowerment, skills development, and providing opportunities for action (Loboka, Shihua, Celestine, Hassan and Wani, 2013). According to Loboka, et al., (2013); Asmawati, Nor and Yusooff, (2011), public awareness, social ideals, beliefs and attitudes to waste can affect all stages in the solid waste management process. This has an impact on household waste storage, waste segregation, recycling (illegal dumping), willingness to pay for waste management services and the level and type of opposition to waste treatment and disposal facilities.

The search for improved environmental quality has driven several governments in developing nations to adopt the use of Environmental Education (EE) in improving the attitude and behavior of its citizenry towards waste management. One will then ask what are undergraduate student's waste management behavior in the universities in Nigeria and University of Calabar in particular? Waste management behaviors are all attitude, disposition and perception towards properly disposing of waste in any environment one finds himself. Waste management behavior include throw away, open dumping, careless attitude towards properly disposing institutional waste like food wrappers, torn books or papers, hotel food remains, vegetable remains etc.. No wonder the United Nations Conference on Climate Change which took place in Copenhagen in December, 2009 generated so much debate among world's leaders and professionals. A degraded environment, writes Soewu (2004) can only offer a degraded quality of life. If we really desire to sustain and improve upon the present quality of life, then it is the collective responsibility of every living human being to secure the quality of the environment.

It has been repeatedly emphasized that there is irrepressible need for entrenching Environmental Education as a leading approach to solving environmental problems and creating a sustainable society. The poor as well as the affluent are equally vulnerable to environmental damage. The poor and poverty- stricken people, wherever they may live, are generally preoccupied with issue of physical survival. They lack money, skills and knowledge and therefore often times, tend to over- utilized local resources beyond sustainable levels. They, therefore need to be empowered to be able to control their resources and therefore their lives according to the tenets of sustainable, safe and clean environment for a healthy living in our societies.

The mission priorities of Environmental Education in schools especially are to:

1. Increase awareness and participation on protecting the quality of environment in schools, by practicing the following

- School sessions run continuously, so a day per week can be kept for clearing, sweeping and cleaning the school environment.

- Summer camps can be held during the holidays (bringing multiple schools together or in one school, hold for youth groups etc).

2. Implement efficient solid waste management by doing thus,

- Compost pits, eco street, segregation of plastic/ metal and glass, papers into degradable and non degradable waste

- $\quad$ Recycling, reduce and reuse, integrating waste to wealth creation

3. Reduce the use of plastic in the school and in communities

- Cotton bag actions involving churches and temples

-preference for leave wrapped goods instead of plastic and polythene wrapped goods 
- Cotton bag actions targeting those who buy groceries instead of polythene bags

- Shop owner support by not using these plastic bags.

4. Improve ties and communication with the community on waste problems including ecological problems and conservation.

- Improve communication with the municipality through opportunities for active member participation in waste management and environmental sanitation.

- Improve communication with self-help groups and others NGOs.

- Improve advertisement against plastic.

- Motivation on community participation in waste management and ecological conservation activities and all other activities which are related to ecology.

The activities associated with the management of solid waste from generation point to final disposal normally include generation, reduction, reuse, recycling, handling, collection, transfer and transport, transformation (e.g. recovery and treatment), and disposal. Depending on site specific conditions, a sound waste management program can be established by combining some of the necessary activities into integrated solid waste management. On the other hand, legislative efforts and effective implementation are vital for the safe management and disposal of solid waste. Incentives may be provided for the development and practice of safe treatments, harmless manufacturing processes and methods for converting solid waste into valuable resource by recycling and reuse.

To aid in proper solid waste management, certain cities have set rules (Matsumoto, 2011; Yin, Gao and Xu, 2014) to necessitate the mandatory segregation of waste at generations level and also the concordance between collection and disposal facilities, to ensure the establishment of local recycling and compositing plants. To ensure the sustainability of any solid waste management (SWM) system, there has to be a change of government perception to that of recognizing the importance of people. The current global challenges of urban solid waste (Ayodeji, 2010). state demand a people centered approach, change in public attitude to consumption and increased relationship between people and the government with new approaches to waste management to tackle the challenges of the increased waste generated by the population, increased cost of waste management leads to increase user chargers. This (Ibid) stated will only be sustainable if the government recognizes the importance of people in planning, designing and operating new solid waste system management (Tan and Teck, 2010).

Bolaane, (2006); Abdul-Muhmin, (2007); D'Souza, Taghian and Khosla, (2007) respectively stated that since waste is a product of human behavior, to maintain a good waste management, we need information on the behavior and attitude of people with regard to waste and accurate data on waste generation. Source separation according to D'Souza, Taghian, Lamb and Peretiatko, (2007) is the setting aside of compostable and recyclable materials from the waste stream before they are collected with other new solid waste to facilitate reuse, recycling, and composting. During the UN conference in Johannesburg in 2002, reduction of waste through source separation was affirmed as one of the steps, which the local government can implement to minimize environmental sound waste reuse, recycling and diversion of useful materials from the waste stream.

Facing out the problems of solid waste management, Mostafa, (2007) argues, can be done through plans and programs which encourage source separation and thus, the author stated will help in minimizing waste for disposal. Higher institutions have the responsibility of having high moral and ethical obligation to the environment because they are expected to produce leaders in environmental protection movement. Asmawati, et al., (2011) research acknowledges the good use of campuses as case study for Solid Waste Management (SWM) options for the following reason.

- They have been independence to a great extent; campuses can accommodate pioneering solid waste management approaches that can filter down to other communities later.

- Since it involves students' at various levels, it can serve to sensitize as well as easily train them in good Solid Waste Management practices.

- Solid waste management practices adopted by higher education institutions have a great potential of being adopted by surrounding communities because these institutions generally are held in high esteem.

The efforts towards responsible waste management should stem from these institutions. Besides, appropriate waste management would bring benefits to the institutions such as a reduction of the financial resources destined to waste management, but, above all, it would set an example to the students and the community. In addition, there seem to be no data on the amount of waste generated and composition in our Nigerian universities. This will help in determining the quantity, composition and recycling potential of the waste generated in University of Calabar. Through source separation, it would help to propose a setup of an integrated waste management program and fill the gap. Since the step was globally taken to include Environmental Education in the educational system, it has emerged in most developing countries as a leading approach to addressing environmental problems and endangering sustainable development.

It is therefore the intention of this paper to give answers to the following questions:

1. What is the waste management behavior of undergraduate students of Environmental Education in the University of Calabar? 
2. What are the waste management methods adopted by students of University of Calabar?

3. What role can Environmental Education play to influence waste management behavior among undergraduate students of the University of Calabar?

Two research hypotheses were also formulated to guide this study thus:

1. Environmental Education does not significantly influence the waste management behavior of undergraduates' students of the University of Calabar.

2. Environmental Education does not significantly influence the waste management methods adopted by undergraduate students.

\section{Methods}

This study adopted the survey inferential research design. The area of study is the Department of Environmental Education, University of Calabar; it is located in Calabar Municipality, which is one of the 18 Local Governments in Cross River State, Nigeria. It lies between latitudes $4^{0} 15^{\prime}$ and $5^{0}$ North and longitude $8^{0} 15^{\prime}$ and $8^{0} 23^{\prime}$ East. There are other tertiary institutions like the Cross River University of Technology (CRUTECH), College of Health Technology, University of Calabar Teaching Hospital, the Federal School of Nursing and Midwifery and the state School of Nursing and Midwifery, Moore Road.

While the department of Environmental Education was established under the consultancy program in 1997 in partnership with the Nigerian Conservation Foundation (NCF), the department as it then was domiciled in the Institute of Education. The department was again removed from the Institute of Education and merged with the department of Curriculum and Teaching, and was again detached and made a full fledge department of its own in 2013/2014 academic session. Department of Environmental Education is one of the thirteen departments that makes up the Faculty of Education in the University of Calabar. The population of this study consists of all undergraduate students of the department of Environmental Education in the Faculty of Education, University of Calabar, which has a total population of about $5 \mathrm{~s} 68$ students in both streams of the program (Consultancy (CES) and Regular (NUC) students).

The program is operated in two streams, the regular students who are the Nigerian University Commission (NUC) who got admission into the department either through UME or Direct Entry through the Joint Admission and Matriculation Board examination which is a four year program and the second stream which is the university operated program through the Center for Educational Services (also known as CES), which is a five year program. Both programs award the same degree, but those for NUC graduate with a teaching subject, while those with the CES program graduate with a professional specialization (Tourism and Eco management, ETE), Women and Environment (EWE), Forestry and Wildlife Resources Management (EFW), Pollution and Waste Management (EPW) and Community Environmental Services (ECS).

Both streams of the program formed the population of the study. The stratified and systematic random sampling technique was used for the selection of the sample used for the study. The entire student population was grouped into the two streams of students (NUC and CES), this was followed by grouping the students into their respective years or level of studies (100 level, 200 level, 300 level, 400 level and 500 levels). This was followed by the selection of individual samples based on the class. A sample of 212 students was selected from both streams for the study.

The instrument for data collection is a fifteen item structured questionnaire. The instrument adopted the four point Likert type response options of Agree (A) Strongly Agree (SA) Disagree (D) and Strongly Disagree (SD). The researchers with the aids of trained class representatives (class reps) administered the instrument to the respondents in their different classes and collected same within two weeks. Simple percentage and Pearson Product Moment Correlation Analysis was used to analyze data generated from the field.

\section{Result and discussion}

Research question 1: What is the waste management behavior of undergraduate students of Environmental Education in the University of Calabar? Table 1 shows the simple percentage analysis

Table 1: simple percentage analysis of the response on the waste management behavior of environmental education undergraduate student in the university of Calabar $(\mathrm{N}=212)$

\begin{tabular}{llllll}
\hline $\begin{array}{l}\text { Class } \\
\text { response }\end{array}$ & $\begin{array}{l}\text { Total sample selected per } \\
\text { class }\end{array}$ & $\begin{array}{l}\text { Throw } \\
\text { away }\end{array}$ & $\begin{array}{l}\text { Percentage } \\
(\%)\end{array}$ & $\begin{array}{l}\text { Dropped into waste } \\
\text { bin }\end{array}$ & Percentage \\
\hline 100 & 56 & 44 & 28.7 & 12 & 20.3 \\
200 & 44 & 38 & 24.8 & 6 & 10.2 \\
300 & 41 & 38 & 24.8 & 3 & 5.1 \\
400 & 50 & 24 & 15.7 & 26 & 44.1 \\
500 & 21 & 9 & 6.0 & 12 & 20.3 \\
Total & 212 & 153 & 100 & 59 & 100 \\
Percentage & 100 & 72.2 & & 27.8 & \\
\hline
\end{tabular}


The result on table 1, shows the responses obtained from the field which indicates that 153 respondents $(72.2 \%)$ believed that most Environmental Education undergraduate students believe in throwing their waste indiscriminately, 59 respondents $(27.8 \%)$ agreed that they manage their waste by dropping them in waste bins provided by the management. This is also segregated into different levels of students. From this simple percentage analysis, most of the respondents under this study have developed the habit of throwing away waste indiscriminately, while only a paltry $27.8 \%$ of the respondents were found to drop their waste into a waste collection bin. The result also shows a specific trend in waste management behavior, those at the final stage of their academic pursuit in the department are found to have positive waste management attitude than fresher's and sophomore, this is observed in the scores of those who believe that waste should be dropped in waste bin and not just thrown away to impede the aesthetic value of the environment.

Research question 2: What are the waste management methods adopted by students of University of Calabar? The result on table 2 shows the methods of waste management adopted by undergraduate students of Environmental Education in the University of Calabar.

The result on table 2 shows that 108 respondents $(50.9 \%)$ observed that the waste management and disposal methods adopted by most students is the open dump method, 59 respondents $(27.8 \%)$ ticked for waste disposal in waste bin within the university, 23 respondents (10.8\%) said they adopt the burning method of waste disposal, while 22 respondents $(10.5 \%)$ ticked for throwing waste into gutters and drainages. From the result of the analysis, it is observed that most of the undergraduate student practice open dump method of waste disposal. The priority in terms of waste management methods adopted by the students are arranged in the order open dump, thrown into waste bin, burning and throwing of waste into drainages and gutter.

Table 1: Showing the waste management methods adopted by undergraduate students of Environmental Education adopts in University of Calabar

\begin{tabular}{lccccc}
\hline \multicolumn{1}{c}{ Class } & \multicolumn{2}{c}{ Waste disposal methods } & & & \\
& Open dump & Disposed in Waste bin & Burning & Thrown into drainage & Total sample \\
\hline 100 & 25 & 14 & 8 & 9 & 56 \\
200 & 24 & 12 & 2 & 6 & 44 \\
300 & 22 & 14 & 5 & -- & 41 \\
400 & 27 & 12 & 6 & 5 & 50 \\
500 & 10 & 7 & 2 & 2 & 21 \\
Total & 108 & 59 & 23 & 22 & 212 \\
Percentage & 50.9 & 27.8 & 10.8 & 10.5 & 100 \\
\hline
\end{tabular}

Research Question 3: What role can Environmental Education play to influence waste management behavior among undergraduate students of the University of Calabar? The result on table 3 shows the role of Environmental Education on student's waste management behavior in the University of Calabar.

From the result on table 3, respondents opinion shows that Environmental Education can play the role of awareness creation about waste management behavior and methods (117 respondents; $55.2 \%)$, carry out advocacy for attitudinal change $(55 ; 25.9 \%)$, provision of waste bin at strategic points in the university $(26 ; 12.3 \%)$ and formulation of environmental policy and legislation (14,6.6\%). Based on this result, Environmental Education can play several roles in influencing undergraduate students waste management behavior, which include the creation of awareness, the effect of waste on environment, health, and aesthetics and for the continuity of environmental services and proper waste management. Once awareness is created, there is the other role of attitudinal change, followed by provision of waste management bin and legislation and policy formulation on waste management in the university.

Table 3: Environmental Education and undergraduate student's waste management behavior

\begin{tabular}{lcccccc}
\hline & $\begin{array}{c}\text { Awareness } \\
\text { creation }\end{array}$ & $\begin{array}{l}\text { Attitudinal } \\
\text { change }\end{array}$ & $\begin{array}{c}\text { Provision } \\
\text { waste bin }\end{array}$ & $\begin{array}{l}\text { of } \\
\text { and legislation }\end{array}$ & $\begin{array}{c}\text { formulation } \\
\text { Total sample }\end{array}$ \\
\hline 100 & 35 & 11 & 8 & 2 & 3 & 44 \\
200 & 20 & 15 & 6 & 2 & 41 \\
300 & 26 & 11 & 2 & 5 & 50 \\
400 & 27 & 12 & 6 & 2 & 21 \\
500 & 9 & 6 & 4 & 14 & 212 \\
Total & 117 & 55 & 26 & 6.6 & 100 \\
Percentage & 55.2 & 25.9 & 12.3 & & 2 \\
\hline
\end{tabular}

Hypothesis one: Environmental Education does not significantly influence the waste management behavior among undergraduates' students of the University of Calabar. The result is presented on Table 4. The result of the Pearson Product Moment Correlation Analysis on table 4 shows that the calculated r-value is 0.84 , while the critical table value is 0.178 , at 210 degree of freedom, since the calculated value of 0.84 is higher than the critical table value of 0.178 , the null hypothesis is rejected, while the alternate hypothesis is accepted, therefore Environmental Education does significantly influence undergraduate student's waste management behavior. The 
implication of this result is that Environmental Education can play a very significant role in influencing the waste management behavior of undergraduate students in the University of Calabar.

This result has also come to confirm the earlier finding of Eneji, et al., (2017) who found that Environmental Education has the capacity to change human behavior, attitude and perception positively towards the management of our environment, waste and other resources. In terms of change of attitude and perception towards management of waste in urban centers, Eneji, et al, (2016) found that most residents of urban centers have very negative attitude towards waste management and disposal, this is so because most persons throw away waste careless in the open, dump in open spaces, throw them into gutter or drainages, and some just discard them anyhow, all these the authors found can be corrected if exposed to Environmental Education.

Table 4: Pearson Product Moment Correlation Analysis of the influence of Environmental Education on undergraduate student waste management behavior in the University of Calabar, $(\mathrm{N}=212)$

\begin{tabular}{lllll}
\hline Variables & $\sum \mathrm{X}$ & $\sum \mathrm{Y}^{2}$ & $\sum \mathrm{XY}$ & $\mathrm{r}$-val \\
\hline Environmental Education & 2051 & 3674 & & \\
Undergraduate students Waste management behavior & & & 56939 & 0.84 \\
\hline
\end{tabular}

Significant 0.05 level, critical $\mathrm{r}=.178, \mathrm{df}=210$.

Similar result was found by Yongsi, (2008); Prabu, (2009) and Tessema, (2010), though the findings and research was domiciled in the urban community not in the school setting. But this has brought about another reason why Environmental Education should be introduced in secondary schools to inculcate the spirit of environmentalism among secondary school students before they become undergraduate students in the universities and other institutions of higher learning. In a similar vein, authors like Modebe (2009); Salam, (2010); and Sankoh, et al, (2013) found a very significant relationship between Environmental Education and students waste management behavior and attitude in tertiary institutions. This result also shows that Environmental Education as a subject has the potential of changing attitude, correcting behavior and directing positive attitude and perception towards waste management in our university system (Mostafa, 2007; Johnston, 2010; Asmawati, Nor and Yusooff, 2011; Eneji, et al., 2015, Eneji, et al., 2016).

Hypothesis two: Environmental Education does not significantly influence the waste management methods adopted by undergraduate students. Table 5 shows the result of the Pearson Product Moment Correlation Analysis of the relationship between Environmental Education and undergraduate student's waste management methods adopted in the University of Calabar. The result of the analysis reveals that the calculated $r$ - value of 0.78 is higher than the critical r- value of 0.178 at 0.5 level of significance with 210 degree of freedom, with this result, since the calculated r-value is 0.78 and the critical table value is 0.178 , the alternate hypothesis is accepted. This therefore means that Environmental Education can significantly influence the waste management methods adopted by undergraduate students in the University of Calabar. The result of this analysis is in line with the findings of Gouveia \& does Prado, (2009); Aatamila, (2010); Iheanacho, et al., (2010) and Yau, (2010) who found that waste management is carried out by a number of processes, many of which are closely interrelated. These methods could inter link or have a melting point where the methods adopted are interwoven with other methods. These authors argue that picking one methods of waste management system does not really make an effective waste management, but a combination of methods could bring a better result. This is the very essence of Environmental Education, which advocates various viewpoints in waste management operations. Therefore it is very logical to design a holistic waste management system, rather than alternative and competing option.

Table 5: Pearson Product Moment Correlation Analysis of the influence of Environmental Education students and methods of waste management $(\mathrm{N}=212)$

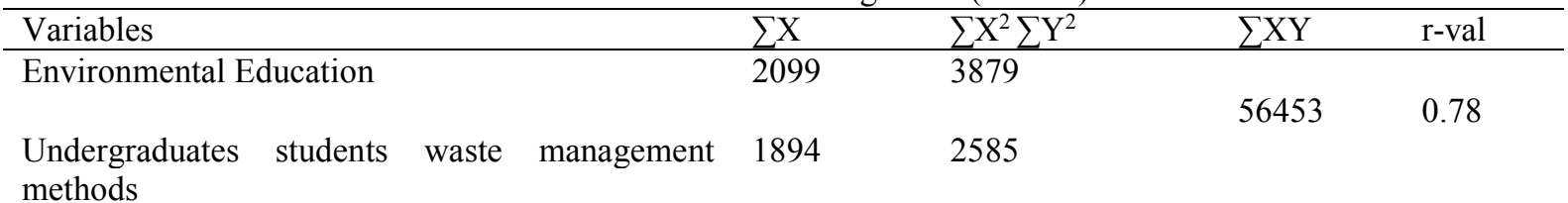

Significant 0.05 level, critical $\mathrm{r}=0.178, \mathrm{df}=210$.

Also in line with this finding is the finding of Wan, et al., (2015) who found that waste is generated in all sorts of ways, its composition and volume largely depend on consumption patterns and the industrial and economic structures of a place. So when waste are generated in whatever means or volume, it is pertinent that such waste are safe and properly managed and disposed to allow for a healthy living and long life.

The findings is in line with the finding of Eneji, et al., (2015), who observed that Environmental Education craves for public awareness, social ideals, beliefs and attitude to waste can affect all stages in the solid waste management process. This has an impact on household waste storage, waste segregation, recycling, illegal dumping, and willingness to pay for waste management services and the level and type of opposition to waste treatment and disposal facilities. The findings is in line with the findings of Yau, (2010) stated that since waste is a product of human behavior, to maintain a good waste management, we need information on the behavior and 
attitude of people with regard to waste and accurate data on waste generation. Also in line with the findings of Wan, et al., (2015), state demand a people centered approach, change in public attitude to consumption and increased relationship between people and the government with new approaches to waste management to tackle the challenges of the increased waste generated by the population, increased cost of waste management leads to increase user chargers.

By this result, it has been established that Environmental Education can change undergraduate student's waste management behavior in the University of Calabar, this is not through a direct change, but through the creation of the needed awareness leading to an attitudinal change, thereby bringing about a total change in waste management behavior. This takes us back to the objective, aims and goals of Environmental Education. The definition of Environmental Education as a subject or course of study which is an education process which creates in the learners the attitude, skills, values, knowledge etc to solve environmental problems while avoiding the creation of new ones. Environmental Education also is a process of creating a world population that is aware of and capable of working individually and collectively towards solving the current environmental problems while reducing or completely stopping the creation of new ones. The objectives also include awareness, knowledge, skills and participation.

It boils down to the fact that an attitude and perception must be formed, this formed attitude brings about the change in behavior and the method best suited to manage and disposed such waste generated in the school including the hostels. Based on this scenario, a sound and sustainable environmental attitude and behavior is needed to make a sound decision on the method to be adopted by undergraduate students for the management and disposal of waste in schools. Based on this trend of reasoning, it is necessary to state that Environmental Education can play a very significant role in the changing of waste management behavior among undergraduate students of the University of Calabar.

\section{Conclusion}

Arising from the result and finding of this research, this researcher concluded that Environmental Education a course of study holds the potential to change our attitude and perception about our environment, thus through its awareness creation, the waste management behavior of undergraduate students can be positively changed for good, while the awareness can also lead to the adoption of most sustainable and safe methods of waste management and disposal among undergraduate students of the University of Calabar.

\section{Recommendations}

Environmental Education should be inculcated into the General Studies courses to give students the pedagogic and rudimentary knowledge about environmental issues including waste management behavior and methods of waste management.

Curriculum planners should give complete nod to the inclusion of Environmental Education as a school subject in Primary and secondary schools across the country, so that students can also sit and write it in their final examinations.

The University of Calabar authority should provide waste bin at different location and also guide and advise students to always drop their waste into these waste bins

Student through peer influence should encourage themselves from the "throw away attitude" and encourage their colleagues to always drop waste in waste bin

Waste management units in University of Calabar should also make it a point of duty to collect waste as soon as the bins are filled, not necessarily waiting for the waste to be spilled to the ground before coming to remove them

Student should also encourage themselves through the student union government carry out weekly or monthly environmental sanitation in schools and in the classrooms and hostels.

Students should be educated on the importance of waste recycling being a good technique of waste disposal.

\section{References}

Aatamila, A............, (2010)“'Odor Annoyance near Waste Treatment Centers: A Population-Based Study in Finland Journal of Air and Waste Management Association, 60(4), 412-418. doi:10.3155/10473289.60.4.412

Abdul-Muhmin, A.G. (2007). Exploring consumers' willingness to be environmentally friendly. International Journal of Consumer Studies, 31: 237-247.

Asmawati, D., Nor, B.A. K. and Yusooff, F., (2011). A Study on the Knowledge, Attitudes, Awareness Status and Behaviour Concerning Solid Waste Management. Procedia Social and Behavioral Sciences 18: 643-648

Ayodeji, I. (2010). Exploring secondary school student understands and practices of waste management in Ogun State, Nigeria. International Journal of environmental and science education. 3 (2): 201-213.

Bolaane, B. (2006). Constraint to promoting people centered approaches in recycling. Habitat international, 30 
(4): 731- 740. doi:desc.ca.gov/hazardouswaste/universalwaste/index.cfm.

D'Souza, C., Taghian, M. and Khosla, R. (2007). Examination of environmental beliefs and its impact on the influence of price, quality and demographic characteristics with respect to green purchase intention. Journal of Targeting, Measurement and Analysis for Marketing, 15(2): 69-78.

Desa, A., Abd Kadir, B. and Yusooff, F., (2012). Environmental Awareness and Education: A Key Approach to Solid Waste Management (SWM) - A Case Study of a University in Malaysia.

D'Souza, C., Taghian, M. Lamb, P. and Peretiatko. R. (2007). Green decisions: Demographics and consumer understanding of environmental labels. International Journal of Consumer Studies; 31: 371-376.

Eneji, C.V.O., (2017). Introduction to Environmental Education. Potsdam, UMC Press

Eneji, C.V. O., Eneji, J. E. O., Ngoka, V.N. and Abang, M., (2016). Attitude towards Waste Management and Disposal Methods and the Health Status of Cross River State, Nigeria. SCIREA Journal of Agriculture; 1(2): 231-247 http://www.scirea.org/journal/Agriculture

Eneji, C.V.O., Asuquo, I., Ray, H.H, Eneji, J.E.O. and Ekpo, C.G. (2015). The Socio-Ecological and Health Implication of Meeting the Challenges of Food Insecurity in the 21 st Century in the Agrarian Society of Cross River, Nigeria. Humanities and Social Sciences Letters; 3(1), 25-136. DOI: 10.18488/journal.73/2015.3.1/73.1.25.36

Gouveia, N. \& do Prado, R.R. (2009). Health Risks in Areas Close to Urban Solid Waste Landfill Sites," Revista de Saúde Pública, 44(5), 1-8.

Ifegbesan, A., (2010). Exploring Secondary School Students' Understanding and Practices of Waste Management in Ogun State, Nigeria. International Journal of Environmental and Science Education; 5(2): 201-215

Iheanacho, S.B.C., Eneji, J.E.O., Undeshi, V.A., Okongor, O.E., Okpiliya, F.I. \& Eneji, C.V.O. (2010). Perception of environmental pollution effects on health of urban dwellers in Calabar Municipality, Nigeria. Journal of Agriculture, Biotechnology and Ecology 3 (1), 162-168

Johnston, H. (2010). Shaping Beliefs and Attitudes: A Handbook of Attitude ChangeStrategies. (on line)

Lee, S. and Hae, S.P. (2011). Korean household waste management and recycling behavior. Building and Environment; 46(5): 1159-1166

Loboka, M. K., Shihua, Q., Celestine, J. L., Hassan, S. O. \& Wani, S. J. (2013). "Municipal solid waste management practices and faced coliform water contamination in the cities of the developing countries, the case of Juba, South Sudan. "International Journal of Environmental Sciences; 3 (50 1614-1624.

Matsumoto, S., (2011). Waste separation at home: Are Japanese municipal curb side recycling policies efficient? Resources, conservation and recycling, 55 (3): 325-334. doi:10.1016/J.reosurce.2010.10.005.

Modebe, I. A., Onyeonoro, U. U., Ezeama, N.N, Ogbuagu, C.N.O, \& Agam N.E. (2009). Public health implication of household solid waste management in Awka, South East Nigeria. The Internet Journal of Public Health; 1(1): 78-91.

Mostafa, M.M. (2007). Gender differences in Egyptian consumers' green purchase behavior: The effects of environmental knowledge, concern and attitude. International Journal of Consumer Studies; 31:220-229.

Pakpour, A.H., Zeidi, I.M., Emamjomeh, M.M., Asefzadeh, S. and Pearson, H., (2014). Household waste behaviours among a community sample in Iran: An application of the theory of planned behaviour. Waste Management; 34(6): 980-986

Prabu, P.C. (2009). Impact of Heavy Metal Contamination of Akaki River on Soil and Metal Toxicity on Cultivated Vegetable Crops. Journal of Environmental, Agricultural and Food Chemistry, 8(9): 818 -827.

Salam, A. (2010). Environmental and Health Impact of Solid Waste Disposal at Mangwaneni Dumpsite in Manzini: Swaziland, ”Journal of Sustainable development in Africa, 12(7): 223-243

Sankoh, F., Yan, X. \& Tran, Q. (2013). "Environmental and Health Impact of Solid Waste Disposal in Developing Cities: A Case Study of Granville Brook Dumpsite, Freetown, Sierra Leone," Journal of Environmental Protection, 4(7), 665-670. doi: 10.4236/jep.2013.47076.

Smith, G. (2010). Sustainability and schools education for interconnection, adaptability education 1, (10) 67-80.

Soewu, D. A., (2004). Proceedings of the global conference on ecological justice and global citizenship conservation awareness education: a panacea for our acting environment.

Tan, B. C. and Teck, C., (2010). Attitude towards the Environment and Green Products: Consumers' Perspective. Management Science and Engineering; 4(2):27-39

Tessema, F., (2010). Overview of Addis Ababa City Solid Waste Management, Presentation at Workshop on Solid Waste Management in Addis Ababa, Ethiopia 18th-20th August.

Wan, C., Shen, G.Q. and Yu, A., (2015). Key determinants of willingness to support policy measures on recycling: A case study in Hong Kong. Environmental Science \& Policy; 54: 409418https://doi.org/10.1016/j.envsci.2015.06.023

Yau, Y., (2010). Domestic waste recycling, collective action and economic incentive: The case in Hong Kong. Waste Management; 30(12): 2440-2447 https://doi.org/10.1016/j.wasman.2010.06.009

Yin, J. and Gao, Y. and $\mathrm{Xu}, \mathrm{H}$. (2014). Survey and analysis of consumers' behaviour of waste mobile phone 
recycling in China. Journal https://doi.org/10.1016/j.jclepro.2013.10.006

of Cleaner Production; 65(15):517-525

Yongsi, H.B.N., (2008). Environmental Sanitation and Health Risks in Tropical Urban Settings: Case study of Household Refuse and Diarrhea in Yaoundé-Cameroon, International Journal of Human and Social Sciences, 3(3): $220-228$. 